Volume 5 | Issue 2 | September, 2014 | 249-252 — e ISSN-2231-6434 |

International Research Journal of Agricultural Economics and Statistics

\title{
Research Paper Economics of production of paddy in Gondia district of Maharastra
}

See end of the paper for authors' affiliations

Correspondence to :

K.H.

PARASHURAMKAR

Department of

Agricultural Economics and Statistics, College of Agriculture, NAGPUR (M.S.) INDIA

Paper History :

Received : 24.03 .2014

Revised : 23.07.2014;

Accepted: 06.08.2014

\section{K.H. PARShURAMKAR, A.S. DAREKAR, S.B. DATARKAR AND U.T. DANGORE}

ABSTRACT : The present study was conducted in Gondia district of Maharastra. The objective was to study the cost and return of paddy production and problems faced by farmers in production of paddy. The result pertaining to this aspect were based on the primary data collected through survey method from Gondia district for the year 2010-11. Ninety paddy growers selected were distributed according to size of land holding i.e. small, medium and large farmers. The study revealed that, per hectare cost of cultivation at overall basis was Rs. 38214.30. Overall per qt. cost of production of paddy growers was Rs. 1016.96. It was higher in large farmers i.e. Rs. 1043.18. The net return obtained on an overall basis was Rs. 5061.47. The highest net return obtained from the large farmers i.e. 6505.4 followed by medium farmers i.e. Rs. 5363.32 and Rs. 3923.87 in small farmers. The input-output ratio on overall basis was 1:1.15 which was higher in large farmers and low in small farmer. Nonavailiability of labour at the time of transplanting and high wages of labour were identified to be the major problems, which need the immediate attention of the policy-makers.

KEY WORDS : Paddy, Cost of return, Problems Paddy cultivators

HOW TO CITE THIS PAPER : Parashuramkar, K.H., Darekar, A.S., Datarkar, S.B. and Dangore, U.T. (2014). Economics of production of paddy in Gondia district of Maharastra. Internat. Res. J. Agric. Eco. \& Stat., 5 (2) : 249-252. 